Journal of Southeast Asian

2019

\title{
One Poem: Light
}

Sengarone Peter Vetsmany

Minnesota State University, Mankato, vetsmany208@hotmail.com

Follow this and additional works at: https://docs.lib.purdue.edu/jsaaea

Part of the Bilingual, Multilingual, and Multicultural Education Commons

\section{Recommended Citation}

Vetsmany, Sengarone Peter (2019) "One Poem: Light," Journal of Southeast Asian American Education and Advancement. Vol. 14 : Iss. 1, Article 8.

DOI: 10.7771/2153-8999.1191

Available at: https://docs.lib.purdue.edu/jsaaea/vol14/iss1/8

This document has been made available through Purdue e-Pubs, a service of the Purdue University Libraries. Please contact epubs@purdue.edu for additional information.

This is an Open Access journal. This means that it uses a funding model that does not charge readers or their institutions for access. Readers may freely read, download, copy, distribute, print, search, or link to the full texts of articles. This journal is covered under the CC BY-NC-ND license. 


\title{
ISAAEA Journal of Southeast Asian American Education and Advancement
}

Vol. 14 Iss. 1 (2019)

\author{
WWW.JSAAEA.org
}

\section{Creative and Literary Works}

\author{
One Poem \\ Sengarone Peter Vetsmany \\ Minnesota State University, Mankato
}

\section{Light 66ฐg}

My grandma rubs my chest, says bo lukkkun,

I listen to her, not rising from table, I open my eyes

to dining room light warming my memories back, commotion eats my ears - uncles argue, Xok cries.

Ma weeps drown light when I look at uncles kneeling beneath window with tumbling sun, on floor Xok screams with no legs, his hand gone. Light is striking - silent flash, an eruption.

I drift off from agony. I recall tree branch I held onto when Xok came running to tree, a cloud diminished his smile, a land mine stole his laughter, a flash brought me back down to dirt.

Eyes open to incense smoke dims light, roams in shadows of war-torn house. Grandma starts to chant a prayer, uncles follow her cadence, I knew when Ma stood beside light.

My brother, who followed me around Lao jungles, who I promised to buy chocolate for when we reach America, will never taste $\quad$ escape. In window, spirits comfort Xok away, his eyes extinguish in candlelight set beside him.

\footnotetext{
C.

SDRERIIGHISRESERNEDR Readers are free to copy, display, and distribute this article, as long as the work is attributed to the author(s) and the Journal of Southeast Asian American Education \& Advancement, it is distributed for non-commercial purposes only, and no alteration or transformation is made in the work. More details of this Creative Commons license are available at http://creativecommons.org/licenses/by-nc-nd/3.0/. All other uses must be approved by the author(s) or JSAAEA. Journal of Southeast Asian American Education \& Advancement, Vol. 14. Iss. 1. (2019) ISSN: 2153-8999
} 


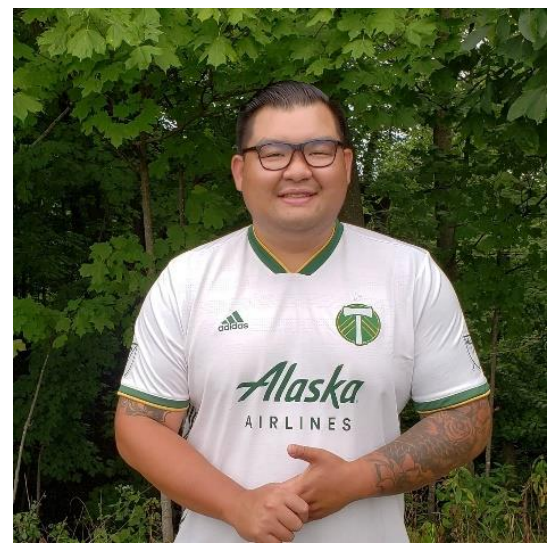

Sengarone Peter Vetsmany, is pursuing a Master of Fine Arts in Creative Writing with an emphasis in poetry at Minnesota State University, Mankato. He is expecting to finish in 2020, which will be just in time for the 45th anniversary of the Lao Diaspora. Born and raised in Boise, Idaho, Peter is a graduate from the University of Idaho with a BS in philosophy. His work has appeared in Little Laos on the Prairie and the Asian American Writers' Workshop. He is the Graduate Assistant for Asian American Affairs at Minnesota State University, Mankato and resides in Minnesota. 


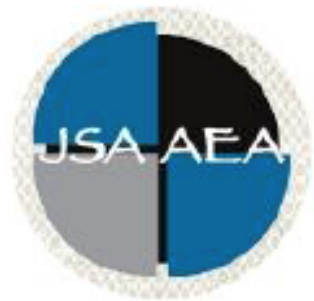

Vol.14 Iss.1 (2019)

\title{
Journal of Southeast Asian American Education and Advancement
}

\author{
www.JSAAEA.org
}

\section{Editor}

Dr. Wayne E. Wright

Purdue University

Associate Editors

Dr. Chhany Sak-Humphry

University of Hawaii at Manoa

Dr. Phitsamay Sychitkokhong Uy

University of Massachusetts, Lowell

\author{
Book Review Editor \\ Dr. Vichet Chhuon \\ University of Minnesota \\ Creative Works Editor \\ Bryan Thao Worra \\ Lao Assistance Center \\ Journal Manager \\ Fang Gao \\ Purdue University
}

\section{Editorial Review Board}

Dr. Steve Arounsack

California State University, Stanislaus

Dr. Sovicheth Boun

Salem State University

Dr. Virak Chan

Purdue University
Dr. Carl L. Bankston III

Tulane University

Dr. Phala Chea

Lowell Public Schools

Dr. George Chigas

University of Massachusetts, Lowell 


\author{
Dr. Loan Dao \\ University of Massachusetts Boston \\ Dr. Changming Duan \\ University of Missouri-Kansas City \\ Dr. Sothy Eng \\ Lehigh University \\ Dr. Vincent K. Her \\ University of Wisconsin, Eau Claire \\ Dr. Peter Nien-Chu Kiang \\ University of Massachusetts, Boston \\ Dr. Kevin K. Kumashiro \\ University of Illinois, Chicago \\ Dr. Ha Lam \\ Eastern Mennonite University \\ Dr. Jonathan H. X. Lee \\ San Francisco State University \\ Dr. Monirith Ly \\ Royal University of Phnom Penh \\ Dr. Bic Ngo \\ University of Minnesota \\ Dr. Leakhena Nou \\ California State University, Long Beach \\ Dr. Mark Pfeifer \\ SUNY Institute of Technology \\ Dr. Loan T. Phan \\ University of New Hampshire \\ Dr. Karen Quintiliani \\ California State University, Long Beach \\ Dr. Angela Reyes \\ Hunter College \\ The City University of New York \\ Dr. Fay Shin \\ California State University, Long Beach \\ Dr. Christine Su \\ College of San Mateo \\ Dr. Alisia Tran \\ Arizona State University \\ Dr. Khatharya Um \\ University of California, Berkeley \\ Dr. Kim Tran \\ University of California, Los Angeles, \\ Glendale Community College \\ Dr. Molly Wiebie \\ The University of Texas at Austin
}

Dr. Hien Duc Do

San Jose State University

Dr. Sophal Ear

Occidental College

Dr. Jeremy Hein

University of Wisconsin, Eau Claire

Dr. Nancy H. Hornberger

University of Pennsylvania

Dr. Peter Tan Keo

New York University

Dr. Yvonne Kwan

San Jose State University

Dr. Ravy Lao

California State University, Los Angeles

Dr. Stacey Lee

University of Wisconsin, Madison

Dr. Sue Needham

California State University, Dominguez Hills

Dr. Max Niedzwiecki

Daylight Consulting Group

Dr. Clara Park

California State University, Northridge

Dr. Giang Pham

University of Massachusetts Amherst

Dr. Malaphone Phommasa

University of Clifornia Santa Barbara

Dr. Kalyani Rai

University of Wisconsin-Milwaukee

Dr. Cathy J. Schlund-Vials

University of Connecticut, Storrs

Dr. Nancy J. Smith-Hefner

Boston University

Dr. Yer J. Thao

Portland State University

Dr. Monica M. Trieu

Purdue University

Dr. Silvy Un

Saint Paul Public Schools

Dr. Linda Trinh Vo

University of California, Irvine

Dr. Yang Sao Xiong

The University of Wisconsin-Madison

Dr. Zha Blong Xiong

University of Minnesota 


\section{Doctoral Student Editorial Review Board}

\author{
Diana Chandara \\ University of Minnesota \\ Bao Diep \\ University of Minnesota \\ Nielsen Hul \\ Cornell University \\ Vanessa Na \\ University of California, San Diego \\ Hoa Nha Nguyen \\ Boston College \\ Linda Marie Pheng \\ University of Wisconsin-Madison \\ Soua Xiong \\ San Diego State University \\ Melissa Vang \\ San Diego State University
}

\author{
Linh Dang \\ University of Rochester \\ Annie BichLoan Duong \\ San Joaquin County Office of Education \\ Dung Minh Mao \\ University of Minnesota \\ Thien-Huong Ninh \\ University of Southern California \\ Khoi Nguyen \\ George Mason University \\ Krissyvan Truong \\ Claremont Graduate University \\ Mai Vang \\ University of Massachusetts Boston \\ Thong Vang \\ University of Minnesota
}

